\title{
The Effect of Fiscal Balance Funds on Local Economic Growth in Indonesia
}

\author{
Priyo Anggono a * \\ ${ }^{a}$ Universitas Indonesia, Depok, West Java, Indonesia
}

\section{INFORMASI ARTIKEL}

\section{Article history:}

Date Submission: 29 July 2020

First revision: 30 July 2020

Accepted: 20 August 2020

Available online: 25 August 2020

Keywords: decentralization, fiscal balance, local economic growth

\section{ABSTRACT}

The fiscal balance funds are the funds from the central government for the local government, and it has become the main revenue for the local governance. As the main revenue, the fiscal balance funds could affect the local economic growth. By looking at the data from the period of 2011 to 2018, this essay investigates two things, first is the relationship between fiscal balance funds and the local economic growth. This essay also identifies what are the major determinants of local economic growth in Indonesia is. Furthermore, do the results differ across regional groups. The essay finds that the relationship between fiscal balance funds have positive effect on economic growth. With the most significant funds are the DAU and DAK. The results also confirm that increasing human capital would increase economic growth. This essay also finds that even though the results for regions vary, capital expenditure still shows positive effect for economic growth. The findings from this essay would have important policy implication for the central government in Indonesia in reviewing the fiscal balance policy and determining the priority sectors

\section{INTISARI}

Dana perimbangan adalah dana dari pemerintah pusat untuk pemerintah daerah, dan telah menjadi sumber pendapatan utama bagi pemerintahan daerah. Dengan demikian, dana perimbangan dapat mempengaruhi pertumbuhan ekonomi lokal. Berdasarkan data dari tahun 2011 hingga 2018, tulisan ini meneliti dua hal, pertama adalah hubungan antara dana perimbangan dengan pertumbuhan ekonomi lokal dan juga mengidentifikasi apa yang menjadi penentu utama pertumbuhan ekonomi lokal di Indonesia. Lebih jauh lagi, apakah hasil antara kelompok regional terdapat perbedaan. Tulisan ini menemukan bahwa dana perimbangan memiliki efek positif pada pertumbuhan ekonomi. Dengan dana paling signifikan adalah DAU dan DAK. Tulisan ini juga mengkonfirmasi bahwa peningkatan sumber daya manusia dapat meningkatkan pertumbuhan ekonomi. Tulisan ini juga menemukan bahwa belanja modal pemerintah daerah masih menunjukkan efek positif bagi pertumbuhan ekonomi. Temuan dari esai ini dapat memiliki implikasi kebijakan yang penting bagi pemerintah pusat di Indonesia dalam meninjau kebijakan keseimbangan fiskal dan menentukan sektor-sektor prioritas. 


\section{Introduction}

Fiscal decentralization could be used to advance the growth of the economy. Fiscal decentralization is convinced to be an effective way to advance the efficiency on providing goods for the public. It is because the local government is believed to be the closest to the people and knows what the people want (Lin \& Liu, 2000; Martinez-Vazquez \& McNab, 2003; Oates, 1999). As the theory, fiscal decentralization is used to let the local government to have more authority in the expenditure. The central government could not interfere on what kind of expenditure that need to be done by the local government.

Moreover, Bloechliger et al. (2016) say that the disparity between local governments could be reversed by fiscal decentralization. However, fiscal decentralization also has negative effects. MartinezVazquez \& McNab (2003) says that fiscal decentralization could make horizontal fiscal disparity between the local governments. This is in the term of revenue that could be extracted by the local government. Because each local government has different capacity to extract the revenue from their territory, and each territory has different resources, local government that could optimize their abilities could gain the upper hand in extracting revenue.

There have been several researches done by some researchers on the study of the relationship between economic growth and fiscal decentralization. Davoodi \& Zou (1998) discovered that in developing countries fiscal decentralization has a negative relationship with the growth of the economy. However, there is no relationship for the developed countries. On the contrary, Lin \& Liu (2000) says that fiscal decentralization has a significant contribution for economic growth. Yet, another study has a mixed conclusion. A study done by Iimi (2005) stated that before the 1990s there is not yet any empirical evidence that could support the relationship of the growth of economic and fiscal decentralization. However, using the data from the year of 1997 until the year of 2001, in the latter of 1990s fiscal decentralization have a positive influence for economic growth.

A study, with Indonesia as the case, by Patunru \& Rahman (2014) stated that fiscal decentralization through the special allocation fund and the implementation of local tax and levies could be optimized. Another study by Sabir et al. (2015) took example of the South Sulawesi province. The study shows that the effect of expenditure of local governments is significant and positive for the growth of economy of the cities and the regencies in South Sulawesi. Furthermore, a study by Savitri et al. (2017) shows that the fiscal balance funds have a positive and significant effect for both west side and the east side of Indonesia. While these researches took the case of
Indonesia, however the scope of the research is regionally or use an outdated data.

One aspect of fiscal decentralization in Indonesia is give authority to local governments to generate revenue. However, the revenue that extracted by the local government could not cover the expenses that need to be spend by them. Thus, the local government needs another source of revenue. Central government could not wash their hand from the issue, so they provide another source of revenue in the shape of fiscal balance fund. The fiscal balance funds mostly consisted fiscal balance fund which is comprised of shared-revenues fund (DBH), general purpose fund (DAU), and special purpose fund (DAK).

Based on the background mentioned above, the relationship of economic growth and fiscal decentralization is yet to be concluded. Moving from there, this study would like to evaluate the effect of fiscal decentralization for economic growth. Even though this study follows the previous studies, there are several differences that is being applied. As other studies only took some part of Indonesia, this study focuses in Indonesia as a whole. Another difference is this study is using the fiscal balance funds as a proxy for the fiscal decentralization. The fiscal balance funds are used to see if there is the local economic growth still has dependency to the central government.

\section{Theory}

In general, the economic growth theory describing about the long-term trend or growth potential (Branson, 2002). It is done by studying the driving factors from overtime and acknowledging the influences of the causes of economic growth. Another theory of economic growth is from classical theory, Keynesian theory, and neoclassical theory.

According to John Maynard Keynes in the 1930s, the output of an economy (Y) is the sum of 4 factors: consumption (C), investment (I), government expenditure $(\mathrm{G})$, and net export which is the difference between exports $(\mathrm{X})$ and imports $(\mathrm{M})$.

$$
Y=C+I+G+(X-M)
$$

According to Keynes, the increase in demand came from one or more of these four factors. However, in the times of recession, demand will decrease due to people reduce their spending. Put everything into consideration, this will decline the investment made by the company. The efforts to improve demand are now in the hands of the government. Government intervention is needed to reduce the effect of an increase (or decrease) in the economic activity. The economic intervention policy that is issued by the government is believed to be able to maintain economic stability. 
The Neoclassical Theory developed by Robert Solow \& Trevor Swan in 1950 stated that economic growth and development came from the addition of the factors affecting aggregate supply. The Solow-Swan model states economic growth (Y) as a function of capital $(\mathrm{K})$, labour force (L), and labour-augmenting technology or knowledge possessed by the workforce (A), which is expressed in the following equation:

$$
Y=f(K, L, A)
$$

In the Solow-Swan models, technological advances are recognized as a driver factor for the economic growth, but this factor is considered as an exogenous factor. For that reason, the Solow-Swan neoclassical equation model is also called the exogenous growth model.

The neoclassical theory does not have any further explain about the factors of technological progress. This limitation is then explained by the theory of endogenous growth which said that the growth of economic is primarily a result of endogenous influences. This theory also states that investment in human capital, innovation, and knowledge contributes significantly to economic growth. According to this theory, in the long run, the level of economic growth depends on the government's policy. For example, several models of economic growth show that policies to provide subsidies in the education sector as well as research and development can increase economic growth.

The endogenous growth model was pioneered among others by Arrow, Romer, \& Lucas. Broadly speaking, the model of endogenous growth states that economic growth $(\mathrm{Y})$ is a function of capital $(\mathrm{K})$, technology (T), labour (L), and human capital $(\mathrm{H})$. The variable of human capital in this model helps explain the contributions to economic growth in addition to the working capital and labour force.

$$
Y=T K_{t}^{\alpha} L_{t}^{\beta} H^{1-\alpha-\beta}
$$

There are three reasons why we link fiscal decentralization with economic growth (Zhang \& Zou, 1998). First is to know the level of efficiency of the resources allocation to provide public goods. Second is to increase the per capita income through the government's policies. Lastly, it takes less effort to measuring and interpreting the economic performance rather than other indicators. However, fiscal decentralization also causes weakness which still require the central government to intervene, since fiscal decentralization have a limitation in the economic gains. In countries where the demand preferences of the people is not homogenous, a decentralized system with sufficient intervention from the central government is required. It is to evade the obstructive effects from 'excessive' regional autonomy and from 'confined' fiscal autonomy, accountability, and responsibility of the local governments (Thiessen, 2003).

Hence the models that built based on the theory of growth effects from fiscal decentralization are not sufficient (Martinez-Vazquez \& McNab, 2003), researchers have tried to analyse and adapt various economic growth models. Moreover, to confirm the link empirically, they also applying various econometric techniques. The powerful potential effects from the government policies on economic growth could be accounted from the theory of endogenous growth models. However, the guide for the empirical work on growth still have no consensus for the theoretical model (Thiessen, 2003).

The model from Davoodi \& Zou (1998), which is a modified version from the Barro's model, is commonly used as analytical framework that links between the fiscal decentralization and economic growth. By implying the Cobb-Douglass production function, it has two inputs: private capital and public expenditure, where the public spending is carried out by three levels of government: federal, state and local. Reallocation of public expenditure between different levels of government could lead to a higher economic growth.

The theories above have become the base of consideration to make the model. The theories, particularly the theory of endogenous economic growth, states that one of the factors that influence economic growth is Capital, which in this model is presented by capital expenditure. Therefore, for this study the proposed equation model is show as follow:

$$
\begin{aligned}
\text { GRDP }_{i t}=\alpha_{1}+ & \beta_{1} \text { Capex }_{i t}+\beta_{2} \text { Capfor }_{i t} \\
& +\beta_{3} \text { LBR }_{i t}+\beta_{4} \text { HDI }_{i t}+u_{1 i}
\end{aligned}
$$

where CAPEX is a function from DAU, DAK, and DBH.

On the proposed equation model, the variables used in this study are proxies or representations of the factors described in the theoretical framework, which are:

a) Gross Regional Domestic Product (GRDP), which is a variable to measure the local economic growth. GRDP is the amount of value added of goods and services from all economic activities in a region;

b) Capital expenditure (Capex), is a variable that represents local government expenditure in the context of capital formation. This expenditure is having a character to become the fixed assets;

c) Gross Fixed Capital Formation (Capfor), is a variable that represents private investment. Capfor is the expenditure on capital goods that have a benefit over than twelve months and is not a consumption goods. Capfor includes residential buildings, roads airports, and as well as machinery and equipment; 
d) The number of workers (LBR), is a variable that shows the workforce aged 15 years and above that works in one area; and

e) Human Development Index (HDI) is an indicator of overall development performance measurements which established by the three basic dimensional approach (Level of health, knowledge, and prosperity).

From the equation above, we also considered CAPEX as a function from the fiscal balance funds of the local government. The description for each variable for CAPEX is as follows:

a) General Allocation Fund (DAU) is the type of transfer that have a nature as a block grant. The using of DAU is not predetermined, so that the local governments could use this fund in accordance with their governance needs;

b) Special Allocation Fund (DAK) is a one type of transfer that have a trait as a specific grant. The utilization of DAK has been arranged for specific activities and must be in accordance with the stipulated provisions. The specific nature of the DAK is it allocated to a certain local government to fund special activities which are local affairs. The special activities itself are part of the national program which become national priorities and become local affairs. Those special activities are activities that are generally related to the basic public functions of government services to the community. This is in line with the function of public services, which is to provide public services to the community through projects such as establishing new roads, constructing drinking water pipes, and supplying sanitations; and

c) Revenue Sharing Funds (DBH) is also fiscal balance fund that has the nature of a block grant as well as DAU. The local governments could use it for various types of expenditure. The sharing comes from tax and natural resources that collected by the central government, and then redistributed to the producing region and the area surround the producing region. Sure enough the producing region gain larger part for the redistribution. It is conducted with the reason is that redistribution of $\mathrm{DBH}$ is carried out based on principle by origin.

The dependent variable in the specifications is the growth rate of the gross regional domestic product (GRDP). While DAU, DAK, and DBH is the variables that represents the revenue from fiscal balance funds. For the expenditure, capital expenditure (CAPEX) is the variables that representing the local governments' expenditure for any fixed assets made. For another independent variables, following Mankiw et al. (1992) the basic determinants for economic growth are regional investment gross fixed capital formation (CAPFOR), the number of labour available (LBR), and indicator of human development index (HDI).

\section{Research Method}

\subsection{Data}

The data used in this essay comes from the local governments' financial report collected from Directorate General of Fiscal Balance, Ministry of Finance and from the Statistics Indonesia (Badan Pusat Statistik). The data from the local governments is the revenue and expenditure data. The revenue itself will come from the intergovernmental transfer from the central government to the local governments in the form of fiscal balance funds. While the expenditure side only use the capital expenditure. The data from Statistics Indonesia are gross regional domestic product (GRDP), regional investment gross fixed capital formation, the number of labour available, and indicator of human development index. The data for this study is taken from the year 2011 until the year 2018. This is following the economic measure which is using the year 2010 as the base year for constant terms and the year 2018 is the year when the latest data is available. The detail of all variables shown in Table 1 below.

Table 1 The Variables Description and Data Source

\begin{tabular}{|l|l|l|}
\hline \multicolumn{1}{|c|}{ Variable Name } & \multicolumn{1}{|c|}{ Description } & \multicolumn{1}{|c|}{$\begin{array}{c}\text { Source of } \\
\text { Data }\end{array}$} \\
\hline \begin{tabular}{l} 
Dependent Variables: \\
\hline $\begin{array}{l}\text { GRDP } \text { it refers } \\
\text { to the GRDP in } \\
\text { the local } \\
\text { government } i \\
\text { and year } t .\end{array}$
\end{tabular} & $\begin{array}{l}\text { The amount of value } \\
\text { added of goods and } \\
\text { services from all } \\
\text { economic activities in } \\
\text { a region. }\end{array}$ & $\begin{array}{l}\text { Statistics } \\
\text { Indonesia }\end{array}$ \\
\hline $\begin{array}{l}\text { Independent Variables: } \\
\text { lDA } U_{i t} \text { is the } \\
\text { general } \\
\text { allocation fund } \\
\text { in the local } \\
\text { government } i \\
\text { and year } t .\end{array}$ & $\begin{array}{l}\text { The type of transfer } \\
\text { that have a nature as } \\
\text { a block grant. }\end{array}$ & $\begin{array}{l}\text { Ministry } \\
\text { of Finance }\end{array}$ \\
\hline $\begin{array}{l}l D A K_{i t} \text { is the } \\
\text { special } \\
\text { allocation fund } \\
\text { in the local } \\
\text { government } i \\
\text { and year } t .\end{array}$ & $\begin{array}{l}\text { The type of transfer } \\
\text { that have a trait as a } \\
\text { specific grant. It } \\
\text { could only be used } \\
\text { for capital } \\
\text { expenditure. }\end{array}$ & $\begin{array}{l}\text { Ministry } \\
\text { of Finance }\end{array}$ \\
\hline $\begin{array}{l}l D B H_{i t} \text { is the } \\
\text { revenue sharing } \\
\text { fund in the } \\
\text { local } \\
\text { government } i \\
\text { and year } t .\end{array}$ & $\begin{array}{l}\text { The type of transfer } \\
\text { that have a nature as } \\
\text { a block grant. The } \\
\text { sharing comes from } \\
\text { tax and natural } \\
\text { resources that }\end{array}$ & $\begin{array}{l}\text { Ministry } \\
\text { of Finance }\end{array}$ \\
\hline
\end{tabular}




\begin{tabular}{|c|c|c|}
\hline Variable Name & Description & $\begin{array}{c}\text { Source of } \\
\text { Data }\end{array}$ \\
\hline & $\begin{array}{l}\text { collected by the } \\
\text { central government, } \\
\text { and then redistributed } \\
\text { to the producing } \\
\text { region and the area } \\
\text { surround the } \\
\text { producing region. }\end{array}$ & \\
\hline $\begin{array}{l}\text { lCapex }_{i t} \text { is the } \\
\text { capital } \\
\text { expenditure in } \\
\text { the local } \\
\text { government } i \\
\text { and year } t \text {. }\end{array}$ & $\begin{array}{l}\text { The representations } \\
\text { of the local } \\
\text { government } \\
\text { expenditure in the } \\
\text { context of capital } \\
\text { formation. }\end{array}$ & $\begin{array}{l}\text { Ministry } \\
\text { of Finance }\end{array}$ \\
\hline $\begin{array}{l}\text { lCapfor }_{i t} \text { is } \\
\text { the private } \\
\text { investment in } \\
\text { the region } i \text { and } \\
\text { year } t \text {. }\end{array}$ & $\begin{array}{l}\text { The representations } \\
\text { of private investment. }\end{array}$ & $\begin{array}{l}\text { Statistics } \\
\text { Indonesia }\end{array}$ \\
\hline $\begin{array}{l}l L b r_{i t} \text { is the } \\
\text { labor in the } \\
\text { region } i \text { and } \\
\text { year } t .\end{array}$ & $\begin{array}{l}\text { The number of } \\
\text { workforces aged } 15 \\
\text { years and above that } \\
\text { works in the region. }\end{array}$ & $\begin{array}{l}\text { Statistics } \\
\text { Indonesia }\end{array}$ \\
\hline $\begin{array}{l}H D I_{i t} \text { is the } \\
\text { indicator of } \\
\text { human } \\
\text { development } \\
\text { index in region } \\
i \text { and year } t .\end{array}$ & $\begin{array}{l}\text { The indicator of } \\
\text { overall development } \\
\text { performance } \\
\text { measurements which } \\
\text { established by the } \\
\text { three basic } \\
\text { dimensional } \\
\text { approach. HDI is not } \\
\text { in logarithmic form } \\
\text { because it is in an } \\
\text { index form. }\end{array}$ & $\begin{array}{l}\text { Statistics } \\
\text { Indonesia }\end{array}$ \\
\hline
\end{tabular}

Source: Analytical result, 2019

Table 2 shows the description of GRDP, fiscal balance funds, capital expenditure, capital formation, number of labor, and the human development index, with the number of observations is 4,007 in total. On average, the level of GRDP in each region is 36.4 million rupiah. The average for fiscal balance for every local government are 897 billion rupiah, which consist of 596 billion rupiah of DAU, 122 billion rupiah of $\mathrm{DBH}$, and 179 billion rupiah of DAK.

The capital expenditure from the local government averaged at 282 billion rupiah, while the capital formation from the private sectors in each region is averaged 363 thousand in US dollar. The number of labor in each region is 242 thousand in average, and the HDI level is 68.27 from 100 .

Table 2 Statistics Descriptive Results

\begin{tabular}{|l|c|c|c|}
\hline \multicolumn{1}{|c|}{ Variable } & Observation & Mean & Std. Dev. \\
\hline grdpbcap & 4,007 & $3.64 \mathrm{e}+07$ & $3.68 \mathrm{e}+07$ \\
\hline Dau & 4,007 & $5.96 \mathrm{e}+11$ & $2.80 \mathrm{e}+11$ \\
\hline
\end{tabular}

\begin{tabular}{|l|l|l|l|}
\hline Dbh & 4,007 & $1.22 \mathrm{e}+11$ & $2.81 \mathrm{e}+11$ \\
\hline Dak & 4,007 & $1.79 \mathrm{e}+11$ & $1.10 \mathrm{e}+11$ \\
\hline Capex & 4,007 & $2.82 \mathrm{e}+11$ & $3.46 \mathrm{e}+11$ \\
\hline capfor & 4,007 & $363,704.9$ & $1,117,984$ \\
\hline Labor & 4,007 & $242,193.9$ & $303,127.3$ \\
\hline Ipm & 4,007 & 68.27872 & 6.657524 \\
\hline
\end{tabular}

Source: Analytical result, 2019

\subsection{Methodology}

This essay uses instrumental variable (IV) to identify the relation between fiscal balance funds to local economic growth. The data that is used has related variables that effect one with the other, which mean there are many endogeneities between the variable. The dependent variable in one equation can act as an independent variable in another equation and the other way around. Khandker et al. (2010) said that the IV methods allow for endogeneity, furthermore it could solve the bias in measurement error. The empirical model (Lewis, 2019) is as follows:

$$
\begin{aligned}
& Y i=\alpha+\beta T i+\varepsilon i \\
& T i=\delta+\gamma Z i+v i
\end{aligned}
$$

Where $Y i$ is the outcome that we want to see, $T i$ is treatment from the variable, and $Z i$ is instrument from variable. In equation (a), the bias would happens when $\operatorname{cov}(\varepsilon i, v i) \neq 0$. The IV estimator denotes by $\beta I V$, where:

$$
\beta_{I V}=\frac{\operatorname{cov}\left(Y_{i}, Z_{i}\right)}{\operatorname{cov}\left(T_{i}, Z_{i}\right)}
$$

There would be unbiased if two assumptions for the IV estimator will be are fulfilled:

$$
\begin{aligned}
& E(T i \mid Z i) \neq 0 \\
& E(\varepsilon i \mid Z i)=0
\end{aligned}
$$

For the first assumption we said that $\operatorname{cov}(T i, Z i) \neq$ 0 which could be also said that $\gamma$ is must be not zero. The next assumption states that an exclusion restriction needed for $Z i$, so in the original model $Z i$ would not be included. In other words, $Z i$ could only affects $Y i$ through Ti.

There is also a downside of the IV method, Khandker et al. (2010) said that it is difficult for the IV method to have good instrument because of two assumptions. The first one is there is no test for the the exclusion restriction. Second, the bias from the IV results is could be huge when the correlation of $Z i$ and $T i$ is weak, eventhough $Z i$ and $\varepsilon i$ is lowly correlated.

Gujarati (2004) said that the two-stage least square (2SLS) method is carried out with the consideration that 
the assumes coefficient reduction obtained not yet able to directly show the relationship of each and every coefficients because there is still other variables that affecting the endogenous variable. Therefore, this essay estimate equation (a) and (b) using 2SLS approach. Gujarati (2004) also state that 2SLS method is to clear the stochastic explanatory from any disturbance. It could be achieved with doing the reduced-form regression for the determined variable on the first stage. After obtaining the results, the second stage is performing the OLS on the transformed equation. Thus, the variables would be consistent, and would be better when there is more sample size.

Therefore, for this study the proposed equation model is show as follow. For the first stage, Capex is a function from DAU, DAK, and DBH. While DAU, DAK, and $\mathrm{DBH}$ is the variables that represents the revenue from fiscal balance funds. The equation for Capex is as follow:

$$
\begin{gathered}
\text { Capex }=\beta_{1}(\mathrm{DAU}, \mathrm{DAK}, \mathrm{DBH})+\beta_{2} \text { Capfor }_{i t}+ \\
\beta_{3} L B R_{i t}+\beta_{4} H D I_{i t}+u_{1 i}
\end{gathered}
$$

From there, the second stage is:

$$
\begin{aligned}
G R D P_{i t}= & \alpha_{1}+\widehat{\beta_{1}} C A P E X_{i t}+\beta_{2} C_{\text {CAPOR }} \\
& +\beta_{3} L B R_{i t}+\beta_{4} H_{i t}+u_{1 i}
\end{aligned}
$$

The dependent variable in the specifications is the growth rate of the gross regional domestic product (GRDP). For the expenditure, capital expenditure (Capex) is the variables that representing the local governments' expenditure for any fixed assets made. For another independent variables, following Mankiw et al. (1992) the basic determinants for economic growth are regional investment gross fixed capital formation (Capfor), the number of labour available (LBR), and indicator of human development index (HDI).

For estimation purposes, this essay will construct a dataset that consist the logarithmic form for the independent and dependent variables. Furthermore, the logarithmic form is used to make sure that the error level is constant. The exceptance is for the variable that already in index form, which is the HDI variable. This output dataset then will be used in the outcome analysis to estimate the effect of fiscal balance fund to the local economic growth.

$$
\begin{aligned}
G R D P_{i t}=\alpha_{1} & +\beta_{1} \text { lCAPEX }_{i t}+\beta_{2} \text { lCAPFOR }_{i t} \\
& +\beta_{3} l_{L B R_{i t}}+\beta_{4} \text { HDI }_{i t}+u_{1 i}
\end{aligned}
$$

\section{Results and Discussion}

This section shows how the results of the calculation is presented. For the first stage, we want to see how strong the correlation between the fiscal balance funds to the dependent variable is, which is the Capex. A summary of the result is in the Table 3:

Table 3 First Stage Summary

\begin{tabular}{|c|c|c|c|c|}
\hline Variable & Coefficient & $\begin{array}{c}\text { Std. } \\
\text { Error }\end{array}$ & T-test & $\mathrm{P}>|\mathrm{t}|$ \\
\hline Indau & .642 & .042 & 15.27 & 0.000 \\
\hline Indbh & .199 & .023 & 8.52 & 0.000 \\
\hline lndak & .316 & .023 & 13.39 & 0.000 \\
\hline
\end{tabular}

Source: Analytical result, 2019

From the calculation we could see that the capex variable is positively and strongly affected by the fiscal balance funds. From the fiscal balance funds variables, DAU is the most influencing factor for the capital expenditure with every $1 \%$ increase of DAU could raise the capital expenditure for $0.64 \%$. From the table we could also see that DAK could raise the capital expenditure by $0.32 \%$, while DBH could only raise $0.2 \%$.

This result shows that even though the number of DAK is not as much as DAU, however because DAK is a specific grant which the usage is already determined only for capital expenditure, the results is reflecting that the DAK funds is right on target. Furthermore, the type of capital expenditure that could be fund by DAK is infrastructure development, which could give more benefits in the long term.

Table 4 Second Stage Summary

\begin{tabular}{|c|c|c|c|c|}
\hline Variable & Coefficient & $\begin{array}{c}\text { Std. } \\
\text { Error }\end{array}$ & z-test & $\mathrm{P}>|\mathrm{z}|$ \\
\hline Incapex & .737 & .029 & 25.30 & 0.000 \\
\hline Incapfor & .003 & .002 & 1.12 & 0.261 \\
\hline Inlabor & .076 & .032 & 2.35 & 0.019 \\
\hline ipm & .012 & .002 & 4.35 & 0.000 \\
\hline
\end{tabular}

Source: Analytical result, 2019

From Table 4 we could see that every sector has positive effect to the economic growth, however the capital expenditure from the government has the most strong and positive effect for the economic growth. The results also confirm that increasing human capital would increase economic growth. Interestingly, the capital formation from the private sector has the lowest effect for the economic growth, for every $1 \%$ rise on capital formation, the economic growth only raises for $0.03 \%$. There could be several reasons on why this is happened. It could be that Indonesia is not an interesting subject to invest or the ease of doing business in Indonesia hamper the investor to invest. A deeper and further research on this subject would need to be done in the future.

Indonesia is a country with many diversities. One region could not be equated with the other region. For 
example, the Sumatera region could not be considered as the same as the Kalimantan region, even though they are in a close vicinity. From that point of view, the second stage regression is recalculated based on the region. There are six regions in this essay, which is the Sumatera region, Java region, Kalimantan region, Sulawesi region, Bali-Nusa Tenggara region, and Papua-Maluku region. The summary results for the western region is shown in Table 5, while the eastern region in Table 6.

Table 5 Second Stage Summary Western Region

\begin{tabular}{|c|c|c|c|}
\hline Coefficient & Sumatera & Java & Kalimantan \\
\hline Incapex & $* 0.976$ & 0.495 & 0.093 \\
\hline lncapfor & 0.004 & 0.001 & 0.016 \\
\hline lnlabor & -0.010 & $* 0.807$ & $* 1.288$ \\
\hline ipm & 0.021 & 0.009 & 0.008 \\
\hline
\end{tabular}

Source: Analytical result, 2019

In the western region, human capital become the most affecting factor for the economic growth. however, the coefficient is not much different between the capital expenditure and number of labors. It also could be said that in Java and Kalimantan region has many laborintensive projects to be done. While in the Java region there are many infrastructure projects, in the Kalimantan region there are many plantation and mining project, especially the coal mines.

Interestingly, while Java and Kalimantan still need many people to work there, the Sumatera region seems to be overcrowded by the labor. It could be the long-term effect of the transmigration program that is done by the New Order government. With the capital expenditure become the not strongest coefficient for the economic growth, it could also be said that these two regions starting to release their dependency to the government sector. However, it is still too early to say that these two regions would fully release their dependency soon.

Table 6 Second Stage Summary Eastern Region

\begin{tabular}{|c|c|c|c|}
\hline Coefficient & Sulawesi & $\begin{array}{c}\text { Bali - Nusa } \\
\text { Tenggara }\end{array}$ & $\begin{array}{c}\text { Papua - } \\
\text { Maluku }\end{array}$ \\
\hline Incapex & $* 0.618$ & $* 0.524$ & $* 0.833$ \\
\hline lncapfor & 0.013 & 0.004 & 0.003 \\
\hline lnlabor & 0.067 & 0.069 & 0.066 \\
\hline ipm & 0.003 & -0.001 & 0.004 \\
\hline
\end{tabular}

Source: Analytical result, 2019

For the eastern region of Indonesia, the capital expenditure that done by the local governments still the most affecting factor for the economic growth in their region. Following the results for Indonesia as a whole and the result for the western region, the number of labors become the next most affecting factor for the economic growth in the eastern region. Just like in the west region, the capital formation by the private sector in the eastern region is the weakest factor for the economic growth.

While this thing is quite surprising for the western region, in the eastern region it is not. As stated before, one of the factors for low capital formation is the ease of doing business. With the eastern region is far from the central government, the information for easing the business is often comes late. Furthermore, the infrastructure in the eastern region is not as good as in the western region. The lack of access to eastern region made the cost for doing business become much more expensive than in the western region. These two factors become the decider factor for the investor to invest in the eastern region.

We could also see that the coefficient of number of labors is not as high in the western region, except for the Sumatera region. It could be mean that there are not enough labor in the eastern region. The majority of the labor could be attracted moving to the western region because there would be many opportunities for them to work because of the labor-intensive projects.

\section{Conclusion}

Economic growth is affected by several factors. The Solow-Swan in the neoclassic theory stated that economic growth is a function of capital, labor, and knowledge. Similarly, the endogen economic growth theory stated the same thing with including the investment on the human capital, thus the endogen economic growth argued that economic growth is a function of capital, labor, technology, and human capital. Furthermore, the Keynesian's theory stated that economic growth is affected by the government and the private sector.

This essay tries to estimate the effect of fiscal balance funds to the local economic growth. The variable that is used are gross regional domestic product (GRDP) as the reflection of local economic growth; fiscal balance funds that consist of general allocation funds (DAU), specific allocation funds (DAK), and revenue sharing funds $(\mathrm{DBH})$; regional investment gross fixed capital formation as the reflection of investment made by the private sector; the number of labour available; and indicator of human development index. All the data is coming from the local governments and the Statistic Indonesia from year 2011 until 2018.

Using the 2SLS method, it is assumed that the fiscal balance funds is affecting the capital expenditure that is done by the local government (first stage), and the capital expenditure with the other variables is affecting the economic growth (second stage). The result of the first stage shows that the fiscal balance funds has positive and strong effect for the local economic growth, with DAU as the most influencing variable. While on the second stage, it is shown that every variable has positive effect for the 
economic growth. However, from all the variables calculated, capital expenditure has the strongest coefficient. Furthermore, the results from the calculation also assure that human capital is also important in increasing economic growth.

The second stage is also done differently. As Indonesia is a wide country and consist of different region, the calculation could be different between the national scope and regional scope. In this essay, Indonesia is divided in six regions, three regions in the western part and three regions in the eastern part. In the western part of Indonesia, the strongest coefficient is the human capital. However, the difference between the coefficient of human capital and capital expenditure is just slightly different. While in the eastern part of Indonesia the strongest coefficient is the capital expenditure. The result for eastern Indonesia region is similar with the result for Indonesia as a whole.

\section{References}

Bloechliger, H., Bartolini, D,. \& Stossberg, S. (2016). Does Fiscal Decentralisation Foster Regional Convergence? (OECD Economic Policy Paper). Paris: OECD Publishing.

Branson, W. (2002). Macroeconomic theory and policy. New Delhi: Nice Printing Press.

Davoodi, Hamid., \& Zou, Heng-Fu. (1998). Fiscal Decentralization and Economic Growth: A CrossCountry Study. Journal of Urban Economics, 32(2), 244-257.

Gujarati, D. (2004). Basic Econometrics (4th ed). NY: McGraw-Hill.

Iimi, A. (2005). Decentralization and Economic Growth Revisited: An Empirical Note. Journal of Urban Economics, 57(3), 449-461.

Khandker, S.R., Koolwal, Gayatri B., \& Samad, H.A. (2010). Handbook on impact evaluation quantitative methods and practices. Washington, D.C: The World Bank.

Lewis, B.D. (2019). Instrumental Variables. Paper presented at lecture for IDEC 8026, The Australian National University, Canberra.

Lin, Justin Yifu., \& Liu, Zhiqiang. (2000). Fiscal Decentralization and Economic Growth in China. Economic Development and Cultural Change, 49(1), 1-21.

Mankiw, N.G., Romer, D., \& Weil, D. (1992). A Contribution To The Empirics of Economic Growth. The Quarterly Journal of Economics, 7(2), 407-437.

Martinez-Vazquez, J., \& McNab, R.M. (2003). Fiscal Decentralization and Economic Growth. World Development, 31 (9), 1597-1616.
Oates, W. (1999). An Essay on Fiscal Federalism. Journal of Economic Literature, 37(3), 1120-1149.

Patunru, A., \& Rahman, E. (2014). Local Governance and Development Outcomes (A). in H Hill (Ed). Regional dynamics in a decentralized Indonesia (pp. 156-185). Pasir Panjang, Singapore: ISEAS Publishing.

Sabir., Yustika, A.E., Susilo., \& Maskie, G. (2015). Local Government Expenditure, Economic Growth and Income Inequality in South Sulawesi Province. Journal of Applied Economics and Business, 3(2), 61-73.

Savitri, M.D., Pratama, A., Anggono, P., Suprapti, P., \& Subagyo, E.N. (2017). Dampak transfer ke daerah dan dana desa terhadap pertumbuhan ekonomi. Jakarta: Ministry of Finance of Indonesia.

Thiessen, U. (2003). Fiscal Decentralisation and Economic Growth in High-Income OECD Countries. Fiscal Studies, 24(3), 237-274.

Zhang, T., \& Zou, Heng-Fu. (1998). Fiscal Decentralization, Public Spending, and Economic Growth in China. Journal of Public Economics, 67(2), 221-240. 